\title{
Г.В. Клюшина
}

\section{ПАЛЕОСЕДИМЕНТАЦІЙНІ УМОВИ ФОРМУВАННЯ ОЛІГОЦЕНОВИХ ВІДКЛАДІВ ПІВНІЧНО- ЗАХІДНОГО ШЕЛЬФУ ЧОРНОГО МОРЯ}

\author{
G. V. Klyushyna
}

\section{PALEOSEDIMENTOLOGICAL CONDITIONS OF FORMATION OF THE OLIGOCENE DEPOSITS OF NORTH-WESTERN SHELF OF THE BLACK SEA}

\begin{abstract}
Викладено результати комплексного вивчення кернового матеріалу зі свердловин північно-західного шельфу Чорного моря. За аналізом аутигенних мінералів з'ясовано фізико-хімічні та гідродинамічні умови седиментогенезу. Охарактеризовано етапи розвитку і седиментаційні умови формування осадків в олігоценовому басейні - планорбеловий, молочанський, керлеутський (рюпель-хатський) час.

Ключові слова: Чорне море, північно-західний шельф, олігоцен, седиментація.
\end{abstract}

\begin{abstract}
Представлены результаты комплексного изучения кернового материала со скважин, пробуренных на северо-западном шельфе Черного моря. По результатам анализа аутигенных минералов выяснены физико-химические и гидродинамические условия седиментогенеза. Охарактеризованы этапы развития и седиментационные условия формирования осадков в олигоценовом бассейне - планорбелловое, молочанское, керлеутское (рюпель-хаттское) время.

Ключевые слова: Черное море, северо-западный шельф, олигоцен, седиментация.
\end{abstract}

The results of the detailed lithological research of Oligocene sediments of north-western shelf of the Black sea on a complex methodical basis are represented in the manuscript. Mineralogical composition, morphological and structural features of detrital, clayey and authigenic components have been identified. The stages of development and sedimentation conditions of precipitation in Oligocene basin - planorbell, molochansk, kerleutsk (ryupel-chattian) time have been described. Keywords: the Black Sea, north-western shelf, Oligocene, sedimentation.

ВСТУП

В межах північно-західного шельфу Чорного моря олігоценові відклади залягають спокійно, практично горизонтально, утворюють розрізи як стратиграфічно повні, так і з численними локальними переривами і характеризуються відмінними структурно-фаціальними особливостями. В генетичному відношенні вони представлені виключно морськими утвореннями, що складають потужну товщу порід. Реконструкція умов осадконакопичення в олігоценовий час грунтувалася значною мірою на даних сучасного осадконакопичення з врахуванням палеоокеанографічної обстановки і фаціальних умов, що існували у той час на досліджуваній території [1, 4, 11].

3 позицій загальних геоісторичних реконструкцій палеогенового періоду олігоцен $€$ регресивною стадією в розвитку палеогенових морських басейнів. Основною причиною їх скорочення була суттєва зміна тектонічної обстановки, яка відбулася на рубежі еоцену й олігоцену і пов'язана з початком значних орогенічних процесів у геосинклінальному поясі Тетісу. Орогенічна активність в геосинклінальних зонах супроводжувалась утворенням великих компенсаційних депресій - накладених внутрішньогеосинклінальних западин и передових прогинів. У порівнянні з еоценом тип порід змінився з кар- бонатного на теригенний, а тропічний клімат на субтропічний $[1,11]$. Головною характерною рисою олігоценового морського басейну є розчленований характер його дна, що являло собою чергування відносно підвищених і різного ступеня заглиблених ділянок. Диференційований характер морфології морського дна багато в чому зумовив відмінність умов седиментації, будови розрізів та їх речовинного складу.

\section{МАТЕРІАЛИ I МЕТОДИ}

Основним геологічним матеріалом для досліджень слугувала колекція кернового матеріалу з пошуково-розвідувальних свердловин північнозахідного шельфу Чорного моря, яка зберігається у відділі сучасного морського седиментогенезу Інституту геологічних наук (ІГН) НАН України. Зразки керна досліджувалися за комплексом методів, що включають детальний макроскопічний опис порід, виділення уламкових фракцій за допомогою водно-механічного, ситового розподілу; вивчення літолого-петрографічних особливостей відібраних фракцій з використанням стандартних методик гранулометричного, хімічного, спектрального, рентгеноструктурного, люмінесцентно-бітумінологічного аналізів.

При проведенні мікроскопічних досліджень значну увагу приділено визначенню фаціальних

(C) Г.В. Клюшина, 2011 
особливостей порід: типу, структури, текстури, співвідношення зерен кварцу і польових шпатів, ступеню обкатаності зерен, вивітрювання польових шпатів, вмісту аутигенних та акцесорних мінералів, органічних решток та ін. При кореляції відкладів враховано також дані промисловогеофізичних досліджень.

\section{ВИКЛАД ОСНОВНОГО МАТЕРІАЛУ}

Олігоценові відклади мають чітку трикомпонентну структуру, яка відображає етапи розвитку морського басейну. Детальне дослідження літологічного складу і фаціальних особливостей відкладів олігоцену дозволило нам охарактеризувати планорбеловий, молочанський, керлеутський етапи розвитку.

В період формування планорбелового етапу в умовах глибоководного відкритого шельфу відбувалось накопичення кремнеземистоглинистих мулів, періодично збагачених на уламковий матеріал. В складі цього етапу виокремлюються два літоцикли. Нижній характеризується седиментацією в спокійних гідродинамічних умовах теригенного алеврито-пелітового матеріалу, який із збільшенням глибини морського басейну змінювався на карбонатноглинистий змішаного біогенно-теригенного генезису. Це особливо відбилося на характері літофацій в районі Каркінітського прогину і Крайового уступу. Ранньопланорбеловий етап розвитку олігоценового басейну був значною мірою успадкованим від еоценового, і зміна умов в ньому відбувалась поступово.

Для верхнього літоциклу притаманною є майже повна відсутність біогенної та теригенної (алевритової) складових. Осадконакопичення відбувалося на значній ділянці шельфу в умовах ослабленої гідродинамічної активності. Розрізи свердловин, пробурених у різних фаціальних зонах, свідчать про однотипність цих відкладів, потужність яких у північно-східній частині шельфу (підняття Західно-Оленівське, Каркінітське, Південно-Голіцинське, Шмідта) сягає 500 м. На кінець планорбелового часу значна частина шельфу, за винятком зовнішньої зони, була покрита тонко- та крупнодисперсними, здебільшого теригенними кремнеземисто-глинистими мулами.

Молочанський етап розвитку олігоценового басейну відрізняється різко відмінними умовами, коли теригенне безкарбонатне осадконакопичення планорбелового часу змінилося на теригенно-карбонатне. Так, в південно-західній частині регіону відбувалося накопичення погано відсортованого теригенного псаміто-алевритоглинистого матеріалу і біогенного карбонату кальцію. Формуванню останнього сприяли підвищені значення Eh і pH [12]. Подальше занурення осадків і перехід до більш відновних умов спричинили утворення тут порівняно невеликої кількості сидериту і піриту.

У східній частині регіону відклади, в цілому, були представлені перешаруванням псамітових, алевритових, псаміто-алевритових і пелітових мулів (підняття Архангельського, Голіцина, Кримське, Південно-Голіцинське, Шмідта та ін.). Геохімічні умови тут були мінливі, про що свідчить склад аутигенних мінералів. Зокрема, наявність аутигенного глауконіту була обумовлена окисним середовищем або перехідним між окисним та відновним [9, 13]. Масове утворення піриту і сидериту пов'язано з частою зміною сильновідновних, відновних і слабковідновних умов, які панували в осадках у періоди седименто- та діагенезу [10]. Формуванню сидериту сприяв значний привніс тонкодисперсної глинистої речовини, збагаченої сполуками заліза. Цьому відповідала палеоседиментологічна обстановка і головним чином ті фактори, що зменшують інтенсивність гідродинамічних рухів (значні глибини, складнодиференційований рельєф морського дна та ін.). Значні концентрації карбонату заліза виникали частково при накопиченні осадку, але головним чином на різних стадіях діагенезу. Періодичне інтенсивне надходження погано відсортованого уламкового матеріалу на деяких площах зумовило накопичення і часте перешарування сидеритових порід з пісковиками, алевролітами і глинами. До таких площ і приурочено більшість відомих на північно-західному шельфі Чорного моря родовищ газу та газоконденсату, що розташовані на бортових частинах Каркінітського прогину.

Свідченням глибоководного характеру басейну, за даними хімічного аналізу, є підвищені значення фосфорного ангідриту. Це може бути пов'язано з фізико-хімічним впливом збагачених фосфором придонних вод на відслонені породи, у зоні прояву апвелінгового ефекту [2, 3].

Найбільший інтерес, передусім з точки зору нафтогазоносності, становить питання про механізм утворення прошарків пісковиків у верхній частині молочанського регіоярусу. Згідно з проведеними дослідженнями, у фаціальному відношенні такі породи є утвореннями таких структурно-фаціальних зон: глибоководної западини, підводного конусу виносу та зовнішнього шельфу. 
Походження уламкового матеріалу в найбільш зануреній зоні басейну, що відповідала району Каркінітського прогину, пов'язано з процесами підводного оповзання на його схилах. В результаті таких процесів відбувалося перевідкладення відносно добре обкатаних переважно кварцових уламків псамітової розмірності та формування прошарків пісковиків, що містять значну домішку алеврито-глинистого матеріалу і входять до складу верхньої карбонатно-піщаноглинисто-алевролітової товщі, що має слабо виражену градаційну шаруватість. Потужність окремих прошарків становить до 0,3 м.

У межах зовнішнього шельфу відбувалося накопичення переважно теригенно-карбонатного матеріалу. Формування тут пісковиків з цементом змішаного глинисто-кальцитового складу відбувалося внаслідок одночасного випадіння в осад теригенного псаміто-алеврито-глинистого матеріалу і біогенного карбонату кальцію. На відповідний розподіл компонентів значний вплив мали придонні течії, що відігравали важливу роль не тільки в транспортуванні мілководного теригенного матеріалу, а також у розмиві і перерозподілі вже сформованих осадків. Псамітові уламки, на відміну від подібних утворень глибоководної западини, мають кутасту форму і більш різноманітний мінеральний склад, що може свідчити про незначне віддалення джерела постачання уламкового матеріалу, тобто надходження певного його обсягу з боку Добруджі. В той же час спостерігаються і спільні для двох фаціальних районів риси, а саме: погане сортування уламкового матеріалу і присутність утворень глауконіту до породоутворюючої кількості. Формування останнього відбувалося на ранній стадії діагенезу морських осадків на етапах уповільненої седиментації і вказує на можливі глибини від 200-300 до 1500-2000 м [13].

Пісковики обох структурно-фаціальних зон пов'язані з порівняно вузьким стратиграфічним інтервалом (верхня частина розрізу молочанського регіоярусу) і сформувалися, вірогідно, в результаті крупної одноактної події. Причиною цього могло бути збільшення тектонічної активності наприкінці молочанського часу, яке супроводжувалося ритмічною зміною гідродинаміки басейну, утворенням суспензійних потоків на схилах підводних підняттів і подальшим транспортуванням завислого матеріалу придонними течіями в умовах відносно глибоководного (сотні метрів) моря. Таким чином, поширення по площі і поєднання в розрізах виділених типів осадків зумовлені чергуванням процесів віднос- но глибоководної седиментації і дією постійних та тимчасових потоків різної щільності. Наслідком цих процесів $є$ періодичне різке зростання вмісту уламків псамітової і алевритової фракцій у відкладах молочанського регіоярусу, наявність ознак механічного сортування за розміром кластичного матеріалу та утворень глауконіту, утворення окатишів глин та алевролітів, які були нами виявлені.

Значно відрізняються фаціальні умови на заході регіону. Тут пісковики зобов'язані появою постійно діючому чиннику, оскільки є відкладами підводного конуса виносу Дунаю, верхня частина якого знаходилася в районі Одеського підняття. Простягався він до району піднятт Штормове. За даними комплексних біостратиграфічних та петрографічних досліджень в північно-західній частині шельфу встановлено більш давні (палеоценову й еоценову) товщі конусів виносу $[7,8]$. Тобто, простежується успадкованість їх розвитку протягом палеогену. Потужність усіх стратиграфічних горизонтів тут також значно скорочена. Фаціальну обстановку осадконакопичення відображено в будові і речовинному складі відкладів товщі по простяганню. Так, у вершинній частині конусу розріз олігоцену представлений перешаруванням погановідсортованих пісковиків, алевролітів і глин (св. Одеська-2, -3, -5), а в найбільш віддаленій - тонкошаруватих глин і переважно дрібнозернистих алевролітів (св. Штормова-2). Тут явно переважало теригенне осадконакопичення, що визначалося інтенсивним зносом з суші, морфоструктурами рельєфу дна, різноманітними придонними умовами, що диференціюють осадовий матеріал.

Дослідження речовинного складу порід керлеутського віку показали, що у пізньоолігоценовий час (хатський ярус) на переважній частині досліджуваної території існували мінливі фаціальні умови, при яких відбувалося накопичення збагаченого органічною речовиною пелітового кременисто-глинистого матеріалу, алевритового та слабовапнистого глинистого.

У нижній частині розрізу керлеутського регіоярусу низкою свердловин (Архангельська-1, -2; Голіцинська-1, -2, -10; Південно-Голіцинська-22; Шмідта-7, -8) розкрито верстви в'язких глин темно-сірого до чорного кольору, що складаються з механічно перемішаної (у різних кількісних співвідношеннях) донними течіями мас теригенно-глинистої та розсіяної органічної речовини. Збагачені ними відклади накопичувалися на початку керлеутського часу в найбільш заглибленій зоні басейну, яка відповідала райо- 
ну Каркінітського прогину, і частково на інших ділянках шельфу (піднятя Сєльського). Головну роль у постачанні органічної речовини відігравав фітопланктон, інтенсивний розвиток якого відбувався на значних глибинах і при відносно низький температурі. Певне значення має знос із суші розчиненої і завислої органіки грунтового покриву. У періоди послаблення вертикальної циркуляції вод відбувалися активні діагенетичні процеси за участю бактеріальної мікрофлори, що призвело до розпаду органічних сполук і формування діагенетичних сульфідних компонентів (стяжінь, піритизації біогенного матеріалу). Подібність цих глин до сапропелево-глинистих та сапропелеподібних мулів голоценового віку [4, $5,7]$ дозволяє припустити однотипність умов їх утворення, зважаючи на те, що в сучасних морських умовах аналогічні відклади характеризують максимально заглиблені ділянки шельфу та континентального схилу.

Подібні відклади керлеутського віку паралелезуются із збагаченими органічною речовиною породами менелітової серії Карпат та майкопськими глинами Кримського континентального схилу Чорного моря [6]. Широке розповсюдження і чітка стратиграфічна приуроченість цих відкладів дозволяють розглядати їх появу як результат загальної зміни кліматичних умов, що сприяло інтенсивному накопиченню органічної речовини в самому басейні седиментації і тим самим створило необхідні умови для формування сульфідів.

Наприкінці олігоценового часу поступово зростає роль іншого біогенного чинника, про що свідчать встановлені нами на межі нижнього міоцену вапнисті глини із рештками черепашок форамініфер і спікул губок.

\section{ВИСНОВКИ}

Проведена реконструкція палеоседиментологічних умов формування олігоценових відкладів північно-західного шельфу Чорного моря дозволяє з певною мірою достовірності говорити про існування в олігоцені відносно глибоководного морського басейну, успадкованого з ранньопалеоценового часу. Очевидно, це був єдиний структурно-геоморфологичний сегмент Тетісу, що мав всі елементи морської седиментації, яка обумовлена морфодинамікою, гідродинамікою, батиметрією, структурою водної товщі і пов'язана з коливаннями рівня Світового океану, кліматичними, тектонічними подіями тощо, що зумовлюють склад і будову фаціальних комп- лексів, контролюють співвідношення різних типів осадків.

Робота виконана в рамках держбюджетної теми відділу сучасного морського седиментогенезу ІГН НАН України "Моніторинг процесів осадконакопичення та оцінка екологічного стану донних відкладів в межах шельфу та континентального схилу Чорного моря".

1. Атлас палеогеографічних карт Української і Молдавської РСР (з елементами літофацій). Масштаб 1:2 500000 / Складачі: Д.Є. Айзенверг, Н.М.Баранова, М. Н. Веклич та ін.; За ред. В. Г. Бондарчука. - К.: Видво АН УРСР, 1960. - 78 арк.

2. Батурин Г.Н. Фосфориты на дне океанов. - М.: Наука, 1978. - 232 с.

3. Геворкян В. Х., Батурин Г. Н., Чугунный Ю. Г. Фосфориты и фосфатизированные породы. - Киев: Наук. думка, 1990. - $188 \mathrm{c}$.

4. Геология шельфа УССР. Литология / Под ред. Е. Ф. Шнюкова. - Киев: Наук. думка, 1985. - 189 с.

5. Гожик П.Ф., Маслун Н.В. Стратиграфія антропогенових відкладів північно-західного шельфу Чорного моря // Матеріали 6-ї Міжнар. конф. “Геодинаміка, сейсмічність і нафтогазоносність ЧорноморськоКаспійського регіону" (Україна, Крим, 12-16 верес. 2005 р.). - Сімферополь, 2005. - С. 45-47.

6. Маслун Н. В., Иноземцев Ю. И., Оровецкий Ю. Ю. Нижнекайнозойские отложения Крымского континентального склона Черного моря (результаты 37 рейса НИС “Академик Вернадский”). - Киев, 1989. - 36 с. - (Препр. / АН УССР. Ин-т геол. наук; 89-13).

7. Осадконакопление на континентальной окраине Черного моря / Ф.А. Щербаков, П. Н. Куприн, Л.И. Потапова и др. - М.: Наука, 1978. - 211 с.

8. Плотнікова Л.Ф., Маслун Н.В., Іванік М.М., Цихоцька Н.Н., Шумнік А.В. Стратиграфія крейдовопалеоценових відкладів та особливості геологічного розвитку західної частини північно-західного шельфу Чорного моря // Геол. журн. - 2003. - № 2. C. 27-38.

9. Пустовалов Л.В. Петрография осадочных пород. М.; Л.: Гостоптехиздат, 1940. - Ч. 1. - 476 с.; Ч. 2 $420 \mathrm{c.}$

10. Теодорович Г.И. Осадочные минералого-геохимические фации // Вопросы минералогии осадочных образований. - Львов: Изд-во Львов. ун-та, 1956. Кн. 3 и 4. - С. 39-56.

11. Чекунов А. В., Веселов А. А., Гилькман А. И. Геологическое строение и история развития Причерноморского прогиба. - Киев: Наук. думка, 1976. - 162 с.

12. Швецов М.С. Петрография осадочных пород. - М.; Л.: Госгеолиздат, 1948. - 387 с.

13. Япаскурт О.В. Литология: Краткий курс (избр. лекции). - М.: Изд-во Моск. ун-та, 2003. - Кн. 1. - 101 с.; Кн. 2. $-2004 .-114$ c.

Інститут геологічних наук НАН України, Київ E-mail: klushina_av@mail.ru

Рецензент - чл.-кор. НАН України О. Ю. Митропольський 